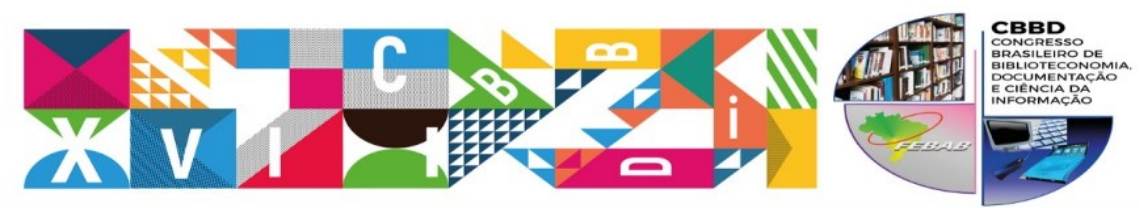

XXVII CONGRESSO BRASILEIRO DE BIBLIOTECONOMIA,

DOCUMENTAÇÃO E CIÊNCIA DA INFORMAÇÃO

TEMA CENTral: Objetivos para o Desenvolvimento Sustentável das Naçōes Unidas:
como as bibliotecas podem contribuir com a implementaçăo da Agenda 2030

Eixo 2 - $3^{\circ}$ Fórum de Biblioteconomia Escolar

\title{
A CONTRIBUIÇÃO DO BIBLIOTECÁRIO ESCOLAR NA FORMAÇÃO DE ESTUDANTES PESQUISADORES NO ENSINO MÉDIO
}

\author{
Jéssica Bedin \\ Doutoranda em Ciência da \\ Informação pela Universidade \\ Federal de Santa Catarina. \\ E-mail: jessicabedin06@gmail.com
}

\section{Magda Teixeira Chagas}

Professora aposentada do Departamento de Ciência da Informação e do Programa de Pósgraduação em Ciência da Informação na Universidade Federal de Santa Catarina. Doutora em Linguística pela Universidade Federal de Santa Catarina.

E-mail: magdatchagas@gmail.com

\section{William Barbosa Vianna}

Professor no Departamento de Ciência da Informação e do Programa de Pós-graduação em Ciência da Informação na Universidade Federal de Santa Catarina. Doutor em Engenharia de Produção pela Universidade Federal de Santa Catarina.

E-mail: wpwilliam@hotmail.com

\section{RESUMO}

A sociedade atual vive em um contexto baseado em informações. Para que as pessoas se apropriem dessas informações e possam aplicar em suas vidas, é preciso tornar consciente a necessidade de usar informações para resolver problemas e construir conhecimentos. A formação na educação básica é um período adequado para iniciar essa preparação e o bibliotecário por meio de sua formação possui conhecimentos para contribuir nessa formação. Dessa forma, questiona-se como os bibliotecários escolares contribuem para a formação de estudantes pesquisadores? O objetivo consiste em mapear as ações dos bibliotecários que contribuem para o desenvolvimento das habilidades em de pesquisa no do estudante. Quanto aos procedimentos metodológicos, trata-se de uma pesquisa exploratória e descritiva, com abordagem qualitativa e pode ser classificada como uma pesquisa bibliográfica. Como resultado da pesquisa, entende-se que os bibliotecários escolares contribuem para a formação de estudantes pesquisadores ao disponibilizarem um espaço apropriado para a pesquisa, também por meio do seu perfil pesquisador promovendo ações que possibilitam potencializar a busca e o uso da informação, fomentando a leitura e desenvolver projetos em parcerias com os professores.

Palavras-chave: Bibliotecário Escolar. Pesquisa Escolar. Estudante Pesquisador. Ensino Médio.

THE CONTRIBUTION OF THE SCHOOL LIBRARIAN IN THE TRAINING OF STUDENT RESEARCHERS IN HIGH

SCHOOL

\section{ABSTRACT}

Current society lives in a context rather than information. To be in their lives, it is necessary to make known the need to use information to solve problems and create knowledge. A 


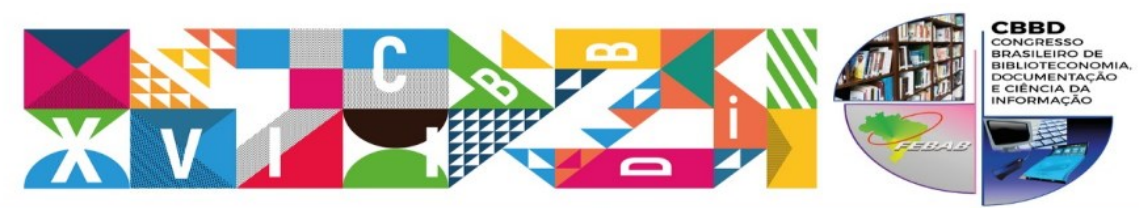

XXVII CONGRESSO BRASILEIRO DE BIBLIOTECONOMIA,

DOCUMENTAÇÃO E CIÊNCIA DA INFORMAÇÃO

TEMA CENTRAL: Objetivos para o Desenvolvimento Sustentável das Naçōes Unidas:
como as bibliotecas podem contribuir com a implementaçăo da Agenda 2030

training in basic education and a suitable period to start this preparation and the librarian through his training with knowledge to contribute to this training. In this way, it is questioned how the school librarians contribute to the formation of student researchers? The objective is to map as actions of librarians that contribute to the development of research skills in the student. As for methodological procedures, this is an exploratory and descriptive research, with a qualitative approach and can be classified as a bibliographical research. As a result of the research, it is understood that school librarians contribute to the training of research students by providing an appropriate space for research, also through their research profile promoting actions that make it possible to search and use information, fostering reading and developing projects in partnerships with teachers.

Keywords: School Librarian. School research. Student Researcher. High school.

\section{INTRODUÇÃo}

A sociedade atual é marcada pelas transformações sociais que são impulsionadas pelo avanço tecnológico. Esse contexto que deu origem a sociedade da informação tem provocado mudanças no paradigma da educação, no qual a aprendizagem passa a ser centrada no estudante e no conhecimento que este obterá para a vida.

Isso implica também, na forma como as pessoas vão usar as informações na resolução de problemas, pois, por se tratar de habilidades básicas para viver na sociedade atual, acredita-se que precisam ser desenvolvidas desde a educação básica, no processo de formação.

Os bibliotecários escolares engajados nas escolas em que atuam, podem desenvolver projetos e ações que viabilizem a concretização de um espaço dinâmico, disponibilizando informações e, possibilitando a aprendizagem por meio de questionamentos e da busca por respostas. Sendo assim, a biblioteca escolar pode ser um espaço valioso no desenvolvimento de habilidades para o entendimento e uso do complexo ambiente informacional em que a sociedade se encontra. 


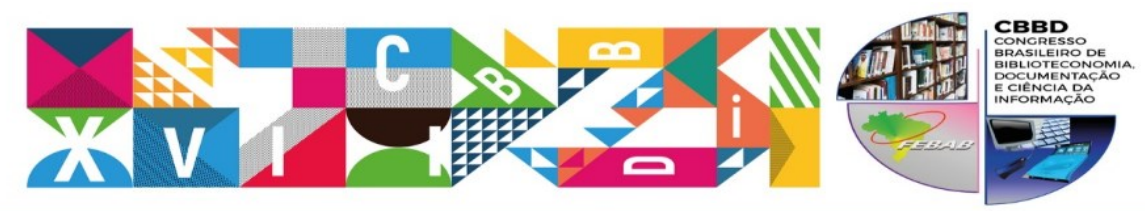

XXVII CONGRESSO BRASILEIRO DE BIBLIOTECONOMIA, DOCUMENTAÇÃO E CIÊNCIA DA INFORMAÇĀO

TEMA CENrRal: Objetivos para o Desenvolvimento Sustentável das Naçōes Unidas:
como as bibliotecas podem contribuir com a implementaçăo da Agenda 2030

Estudante pesquisador nesta pesquisa refere-se ao estudante que no ensino médio é incentiva à desenvolver suas habilidades de pesquisa e criticidade, exigidas na sociedade da informação frente aos acontecimentos e mudanças.

Neste artigo, tem-se como tema as ações do bibliotecário para a formação de estudantes pesquisadores. Busca-se resposta para a seguinte problemática: Como os bibliotecários escolares colaboram para a formação de estudantes pesquisadores, no ensino médio de escolas particulares de Florianópolis/SC?

Assim, objetiva-se investigar a atuação do bibliotecário escolar na formação de estudantes pesquisadores, no ensino médio, nas escolas particulares de Florianópolis/SC. Para o cumprimento deste objetivo geral almeja-se especificamente: a) caracterizar as bibliotecas das escolas particulares de Florianópolis/SC; b) verificar o perfil dos bibliotecários atuantes nessas bibliotecas; c) mapear as ações dos bibliotecários que contribuem para o desenvolvimento das habilidades em pesquisa no estudante.

A pesquisa justifica-se no campo científico por preencher lacunas existentes nos estudos voltados à pesquisa escolar no ensino médio. E no campo social por potencializar e dar visibilidade para a biblioteca escolar e consequentemente para a atuação do bibliotecário, no que se refere à educação e à aprendizagem, por meio da pesquisa escolar.

Ademais, este artigo está estruturado da seguinte forma: a primeira seção abrangendo a introdução, com a contextualização, problema, objetivo e justificativa; a segunda seção compreende a fundamentação teórica sobre biblioteca escolar na sociedade da informação; a terceira seção com a fundamentação teórica, a respeito da pesquisa escolar como uma estratégia de aprendizagem e prática básica das atividades humanas; a quarta seção apresenta os procedimentos metodológicos; a quinta seção discute os resultados e análises e a sexta seção as considerações finais, e por fim, as referências utilizadas no desenvolvimento da pesquisa.

\section{A BIBLIOTECA ESCOLAR}

A sociedade da informação é marcada pela presença da informação e do conhecimento nos mais diversos setores e níveis sociais. Em nível global, a informação 


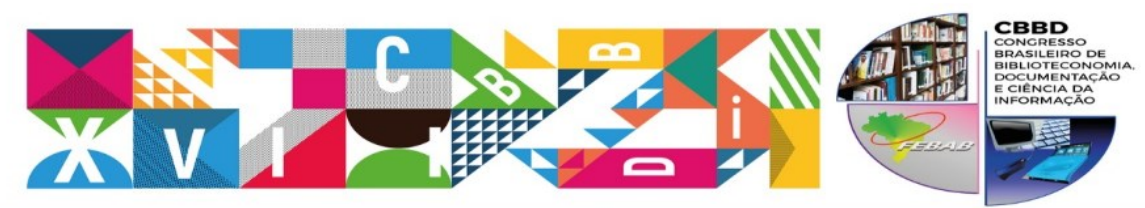

XXVII CONGRESSO BRASILEIRO DE BIBLIOTECONOMIA,

DOCUMENTAÇÃO E CIÊNCIA DA INFORMAÇĀO

TEMA CENrRaL: Objetivos para o Desenvolvimento Sustentável das Naçōes Unidas:
como as bibliotecas podem contribuir com a implementaçăo da Agenda 2030

situa o mundo, possibilita ao indivíduo conectar-se com o passado, o presente e o futuro. Barreto (1994, p. 1) acredita que "a informação, quando adequadamente assimilada, produz conhecimento, modifica o estoque mental de informações do indivíduo e traz benefícios ao seu desenvolvimento e ao desenvolvimento da sociedade em que ele vive".

Takahashi (2000, p. 43) chama a atenção para a educação, pois a considera "elemento-chave na construção de uma sociedade baseada na informação, no conhecimento e no aprendizado". É por meio da educação que se geram novas possibilidades, para ir além, rompendo barreiras e quebrando paradigmas. A autora completa:

[...] educar em uma sociedade da informação significa muito mais que treinar as pessoas para o uso das tecnologias de informação e comunicação: trata-se de investir na criação de competências suficientemente amplas que lhes permitam ter uma atuação efetiva na produção de bens e serviços, tomar decisões fundamentadas no conhecimento, operar com fluência os novos meios e ferramentas em seu trabalho, bem como aplicar criativamente as novas mídias, seja em usos simples e rotineiros, seja em aplicações mais sofisticadas (TAKAHASHI, 2000, p. 43).

0 grande desafio na sociedade da informação é conscientizar e preparar os indivíduos para viver em um ambiente rico em informação. Ações voltadas para o domínio no uso das fontes de informação e a transformação da informação em conhecimento são marcas registradas da biblioteca e da sociedade da informação.

Furtado (2000) observa que o paradigma da educação está voltado para aprender a aprender, isto é, preparar o estudante para

[...] adquirir habilidade para aprender, saber obter, utilizar e gerar nova informação; os sistemas de informação tornam-se extremamente importantes, pois podem contribuir para a sua democratização, ou seja, facilitar e aumentar o seu acesso e, mais ainda, contribuir para que a informação recebida transforme-se em conhecimento, melhorando a qualidade de vida dos cidadãos (FURTADO, 2000, não paginado). 


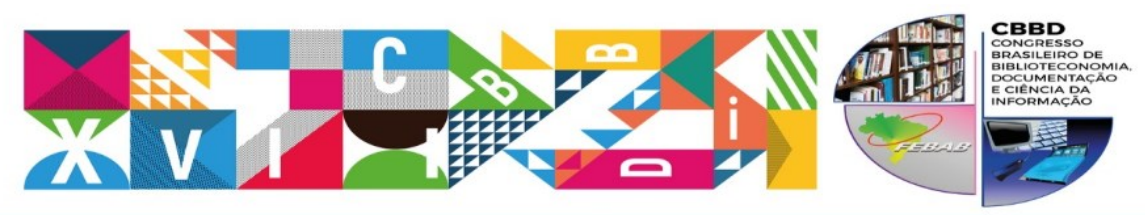

XXVII CONGRESSO BRASILEIRO DE BIBLIOTECONOMIA,

DOCUMENTAÇÃO E CIÊNCIA DA INFORMAÇÃO

TEMA CENTRAL: Objetivos para o Desenvolvimento Sustentável das Naçōes Unidas:
como as bibliotecas podem contribuir com a implementaçăo da Agenda 2030

As tecnologias de informação e comunicação viabilizam o acesso às informações, mas é o indivíduo quem se apropria e gera transformações na sociedade. Saracevic (1996, p. 43) considera que "atualmente, transmitir conhecimento para aqueles que dele necessitam é uma responsabilidade social, e essa responsabilidade social parece ser o verdadeiro fundamento da Ciência da Informação".

Assim, esta pesquisa relaciona-se aos estudos voltados para a utilização da informação, e principalmente na formação de indivíduos capazes de buscar, assimilar e usar efetivamente a informação em suas vidas. No sistema educacional, a biblioteca escolar é fundamental, sendo considerada o local apropriado para o desenvolvimento de habilidades informacionais nos estudantes, tendo em vista que a sociedade da informação exige dos indivíduos um processo contínuo de aprendizagem.

Nesse cenário, na biblioteca tem-se a preocupação de organizar o saber, e principalmente de sistematizar o acesso às informações, deixando de ser um tesouro, preocupando-se apenas em guardar o saber. A biblioteca transforma-se em serviços e os livros materias de consumo, contribuindo com as transformações sociais (MILANESI, 1983).

No que se refere à biblioteca escolar, objeto de estudo desta pesquisa, pode-se afirmar que a mesma apresenta um papel fundamental na sociedade da informação. Isso se concretiza pelo fato de na biblioteca organizar-se e mediar-se a informação à comunidade escolar, e principalmente por preparar-se as pessoas para a busca e o uso da informação.

Pimentel, Bernardes e Santana (2007) ressaltam que ao definir o conceito de biblioteca, é importante levar em consideração a tipologia, pois esta auxilia na percepção da função social e no conhecimento específico da comunidade. Neste caso, a Biblioteca escolar

[...] localiza-se em escolas e é organizada para integrar-se com a sala de aula e no desenvolvimento do currículo escolar. Funciona como um centro de recursos educativos, integrado ao processo de ensinoaprendizagem, tendo como objetivo primordial desenvolver e fomentar a leitura e a informação. Poderá servir também como suporte para a 


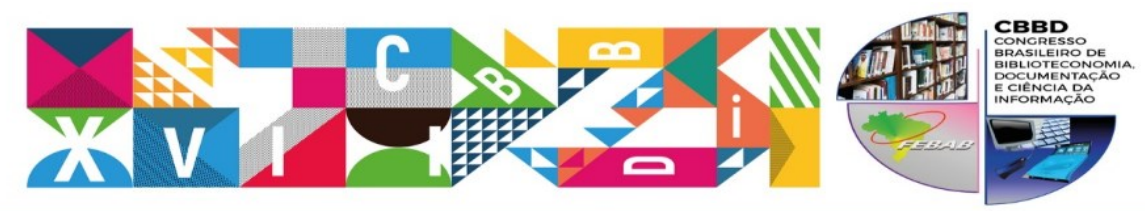

XXVII CONGRESSO BRASILEIRO DE BIBLIOTECONOMIA,

DOCUMENTAÇÃO E CIÊNCIA DA INFORMAÇÃO

TEMA CENTRAL: Objetivos para o Desenvolvimento Sustentável das Naçōes Unidas:
como as bibliotecas podem contribuir com a implementação da Agenda 2030

comunidade em suas necessidades (PIMENTEL; BERNARDES; SANTANA, 2007, p. 23).

De acordo com Chagas (2009), nas bibliotecas escolares, assume-se um papel importante, devido ao compromisso de que estas sirvam como mediadoras entre os leitores e os documentos, e consequentemente todo o conhecimento registrado nestes. Considerando então, que o ambiente escolar possui características próprias, na biblioteca, necessita-se ofertar recursos informacionais condizentes com o perfil de seus estudantes, para que a aprendizagem seja efetivada (FUSSATO; SILVA, 2014).

No processo de ensino aprendizagem, Durban Roca (2012) entende que para ter um ensino de qualidade é preciso visualizar a biblioteca escolar como um recurso educacional. A autora complementa

\footnotetext{
A biblioteca escolar é um recurso facilitador de processos de ensino e aprendizagem. Nesse sentido, relaciona-se e vincula-se com a implementação de novas tecnologias nas escolas. As duas realidades se posicionam no sistema escolar como meios de ensino (DURBAN ROCA, 2012, p. 24).
}

Para Campello (2010, p. 7), as bibliotecas escolares "são espaços de aprendizagem que propiciam e estimulam conexões entre saberes; que são laboratórios, não de equipamentos e apetrechos, mas de ideias". Para construir conhecimento e desenvolver a aprendizagem, a pesquisa escolar é vista como um processo facilitador, dessa forma, na próxima subseção, será apresentado seus conceitos.

\section{A PESQUISA ESCOLAR}

A pesquisa faz parte da vida das pessoas, uma vez que fazer compras, procurar emprego, pagar as contas do mês, procurar informações que lhe interessam, alugar uma casa, ver a previsão do tempo - é fazer pesquisa. Bagno (2007, p. 18) observa que, é “difícil imaginar qualquer ação humana que não seja precedida por algum tipo de investigação".

Com as variadas fontes de informações que estão disponíveis, e contrapondo com os problemas e decisões diários que surgem no dia a dia, pesquisar, questionar, comparar, Revista Brasileira de Biblioteconomia e Documentação - v. 13, n. esp. CBBD 2017 


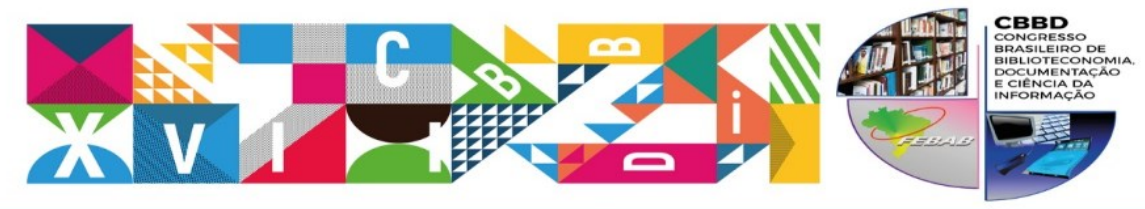

XXVII CONGRESSO BRASILEIRO DE BIBLIOTECONOMIA, DOCUMENTAÇÃO E CIÊNCIA DA INFORMAÇĀO

TEMA cENrRal: Objetivos para o Desenvolvimento Sustentável das Naçōes Unidas:
como as bibliotecas podem contribuir com a implementaçăo da Agenda 2030

comprar, tirar dúvidas, são atividades simples que se processadas com informação geram impacto nas decisões e, consequentemente, em nossas vidas. Desse ponto de vista, tornar esse processo uma atividade consciente e crítica são fundamentais na sociedade do conhecimento.

Tendo em vista o quanto a pesquisa está presente na sociedade, Bagno (2007, p. 21) observa que a pesquisa acontece em pelo menos quatro situações: "no dia-a-dia, nas ações mais corriqueiras; no desenvolvimento da ciência; no avanço tecnológico e no processo intelectual de um indivíduo".

$\mathrm{Na}$ construção do conhecimento, a estratégia de aprendizagem por meio da pesquisa escolar não se limita a um simples levantamento de informações, seja de um conceito ou histórico sobre um determinado assunto. Para visualizar o quanto a pesquisa é vista e feita de forma equivocada, Rasche (2010, p. 23) apresenta o seguinte exemplo, que representa muito bem a realidade atual "uma rápida olhada na Internet, utilizando a ferramenta Google, com o termo de busca "pesquisa escolar" nos mostra o quanto essa prática de pesquisa é vista de maneira simples e equivocada".

Se os estudantes se encontram desamparados para realizar as atividades de busca da informação, consequentemente encontram-se incapacitados para se apropriar e construir conhecimento. Se a atividade de pesquisa é vista como uma atividade para apenas responder a uma pergunta feita pelo professor, um copia e cola, não apresentando significado para o estudante, certamente não contribuirá na construção de seu conhecimento, muito menos de um espírito científico (PIERUCCINI, 2007).

Quando se trata de pesquisa escolar, Pieruccini (2007) chama a atenção para o fato de que a busca da informação é deixada nas mãos de um público que não foi preparado a pesquisar, nem no ambiente escolar, nem em casa, e espera-se que a construção do conhecimento aconteça natural e espontaneamente, sem orientação para que se realize.

Essa mera atividade de pesquisa, apresentada acima é vista e comprovada pelos educadores como prejudicial aos estudantes, pois está limitada a uma resposta pronta, muitas vezes baseada apenas em uma fonte de informação, sem o mínimo de questionamento e dúvidas, que provoquem a reflexão e a aprendizagem (RASCHE, 2010). 


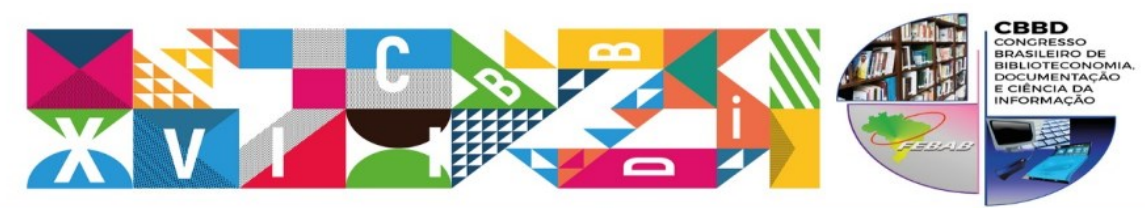

XXVII CONGRESSO BRASILEIRO DE BIBLIOTECONOMIA,

DOCUMENTAÇÃO E CIÊNCIA DA INFORMAÇĀO

TEMA cENTrRL: Objetivos para o Desenvolvimento Sustentável das Naçōes Unidas:
como as bibliotecas podem contribuir com a implementaçăo da Agenda 2030

Campello (2012, p. 7) ressalta ainda, que "boas bibliotecas propiciam uma aprendizagem peculiar, diferente daquela em que o aluno é um recipiente passivo de informações passadas pelo professor". Essas bibliotecas possuem um diferencial na aprendizagem, sendo o próprio estudante quem constrói seu conhecimento, por meio da pesquisa, consultando fontes informacionais, "extraindo delas significados e agregando suas próprias experiências".

Para Kuhlthau (2010, p. 29), o "processo de pesquisa consiste na concepção de ideias por meio de informações à medida que elas são localizadas, lidas e compreendidas". Para Moro e Estabel (2004) a pesquisa escolar tem como princípios básicos

[...] auxiliar o aluno a estudar com independência, planejar, conviver e interagir em grupo, aceitar as opiniões dos outros, usar adequadamente a biblioteca, utilizar as fontes de consulta, desenvolver o pensamento crítico e o gosto pela leitura, adquirir autonomia no processo de conhecimento, aprender a trabalhar colaborativa e cooperativamente, entre outros (MORO; ESTABEL, 2004, p. 1).

Campello (2010, p. 29) acredita que "para o estudante, aprender o processo de busca de informação é tão importante quando expandir seu conhecimento sobre determinado assunto". Essa ideia de preparar o estudante para experiências que vão além das atividades escolares, abrangendo atividades do cotidiano é sempre ressaltada por Campello.

A biblioteca escolar é, sem dúvidas, o espaço por excelência para
promover experiências criativas de uso da informação. Ao reproduzir o
ambiente informacional da sociedade contemporânea, a biblioteca pode,
através de seu programa, aproximar os alunos de uma realidade que ele
vai vivenciar no dia-a-dia, como profissionais e como cidadão
(CAMPELLO, 2008, p.11).

A pesquisa escolar é conceituada por Rasche (2010, p. 9) como uma "estratégia de ensino aprendizagem que propicia a construção do conhecimento por meio de uma prática investigativa, seguida de organização e análise de um conjunto de informações”. E 


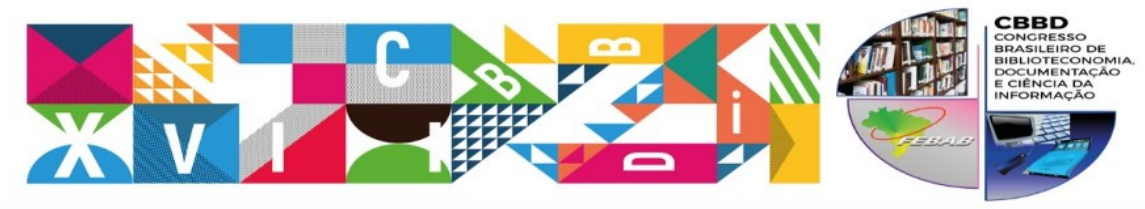

XXVII CONGRESSO BRASILEIRO DE BIBLIOTECONOMIA, DOCUMENTAÇÃO E CIÊNCIA DA INFORMAÇĀO

TEMA CENrRal: Objetivos para o Desenvolvimento Sustentável das Naçōes Unidas:
como as bibliotecas podem contribuir com a implementaçăo da Agenda 2030

para finalizar esse processo o conhecimento obtido é externalizado ou compartilhado, por meio de trabalhos escritos ou apresentados oralmente.

Ademais, Rasche (2010, p. 9) observa que é "preciso que ela seja parte de um projeto de educação mais abrangente, [...] que haja estrutura capaz de sustentar a adoção desta estratégia de ensino aprendizagem".

Para que ocorra a construção do conhecimento junto aos estudantes, é essencial desenvolver uma consciência crítica sobre a pesquisa escolar, algo que faça sentido, que o estudante tenha claro o porquê, para quê e como buscar informação. Este processo é que viabiliza a construção do conhecimento (PIERUCCINI, 2007).

Além de ter clareza nas questões citadas acima, é interessante que o bibliotecário e o professor ao solicitar a pesquisa escolar

[...] relembre aos alunos os procedimentos que podem servir de orientação para o início, o desenvolvimento e a conclusão do trabalho, tais como: o que, de que trata o trabalho, para que será realizado, quanto (dimensão), quando (prazo para entrega), onde o assunto pode ser encontrado e como forma da comunicação do trabalho (MORO; ESTABEL, 2004, p, 2).

O compromisso da escola, incluindo a biblioteca, vai além de transmitir conteúdos, é preciso ensinar a aprender. Isso envolve oportunizar aos estudantes caminharem sozinhos às fontes de conhecimentos disponíveis na sociedade que hoje é caraterizada por um bombardeio de informação (BAGNO, 2007).

Bagno (2007, p. 15) observa que ensinar a aprender é mais que mostrar os caminhos; é sobretudo "orientar o estudante para que desenvolva um olhar crítico que lhe permita desviar-se das "bombas" e reconhecer, em meio ao labirinto, trilhas que conduzem às verdadeiras fontes de informação e conhecimento".

Para desenvolver e instigar o raciocínio crítico é preciso criar oportunidades para debates na biblioteca escolar. Segundo Vidotti, Lanzi e Ferneda (2014, p. 128-129) "essas ocasiões fazem os alunos interpretar situações e refletir sobre diversos aspectos para ter uma visão detalhada sobre determinado tema. Faz com que eles busquem mais informações sobre o assunto, ou queiram saber mais". 


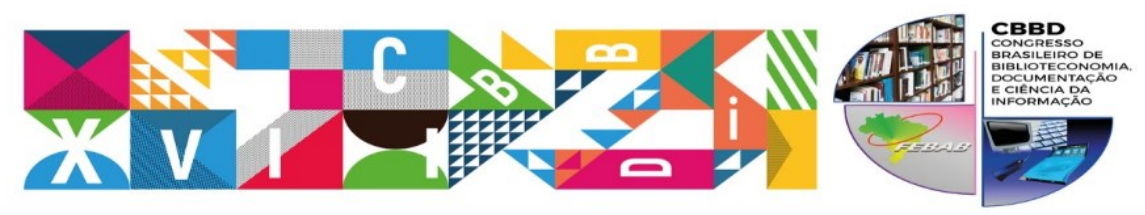

XXVII CONGRESSO BRASILEIRO DE BIBLIOTECONOMIA,

DOCUMENTAÇÃO E CIÊNCIA DA INFORMAÇÃO

TEMA CENTraL: Objetivos para o Desenvolvimento Sustentável das Naçōes Unidas:
como as bibliotecas podem contribuir com a implementaçăo da Agenda 2030

Com base nos benefícios da atividade de pesquisa, Campello (2012) observa que o bibliotecário pode incorporar à sua prática métodos de ensino, baseados em fatos e informações comprovados cientificamente, e que garantem certa eficiência nas ações, por serem obtidos por meio de pesquisas na universidade. No caso da pesquisa na biblioteca escolar, existem vários métodos baseados em estudos científicos que podem auxiliar e qualificar a prática do bibliotecário (CAMPELLO, 2012). Na seção a seguir, será apresentados os procedimentos metodológicos utilizados.

\section{PROCEDIMENTOS METODOLÓGICOS}

Nesta sessão, são apresentados os procedimentos metodológicos para alcançar o objetivo proposto. Primeiramente, são estabelecidas as formas clássicas de classificar as pesquisas, em seguida as etapas de desenvolvimento da pesquisa.

$\mathrm{Na}$ perspectiva de seus objetivos, trata-se de uma pesquisa exploratória e descritiva. Gil (2010) observa que a pesquisa exploratória pretende oportunizar uma maior familiarização com o problema deixando-o mais explícito. Pode envolver levantamento bibliográfico, entrevista com indivíduos que tiveram conhecimentos práticas com o problema pesquisado e análise de bons exemplos que estimulem a compreensão. Em relação à pesquisa descritiva, Gil (2010) observa que esta tem o propósito de descrever as características de uma determinada população ou fenômeno, por meio de técnicas de coleta de dados padronizados. Geralmente, assume a forma de levantamento.

Do ponto de vista de sua natureza, esta dissertação é considerada uma pesquisa aplicada. Silva e Menezes (2005, p. 20) ressaltam que este tipo de pesquisa "objetiva gerar conhecimentos para aplicação prática e dirigidos à solução de problemas específicos. Envolve verdades e interesses locais". Quanto à abordagem do problema, a pesquisa é considerada qualitativa. Minayo (2009) considera que:

A pesquisa qualitativa responde a questões muito particulares. Ela se ocupa, nas Ciências Sociais, com um nível de realidade que não deveria ser quantificado. Ou seja, ela trabalha com o universo dos significados, Revista Brasileira de Biblioteconomia e Documentação - v. 13, n. esp. CBBD 2017 


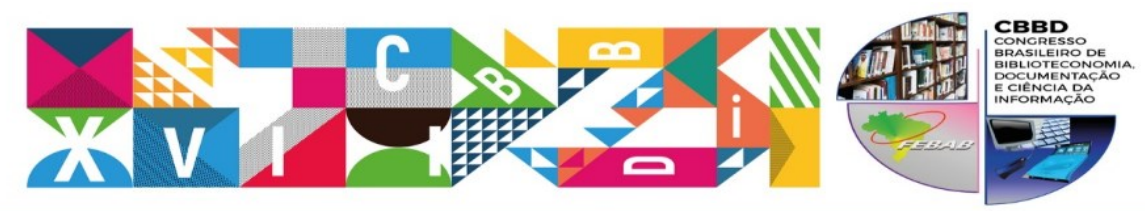

XXVII CONGRESSO BRASILEIRO DE BIBLIOTECONOMIA,

DOCUMENTAÇÃO E CIÊNCIA DA INFORMAÇÃO

TEMA CENTRAL: Objetivos para o Desenvolvimento Sustentável das Naçōes Unidas:
como as bibliotecas podem contribuir com a implementaçăo da Agenda 2030

dos motivos, das aspirações, das crenças, dos valores e das atitudes. Esse conjunto de fenômenos humanos é entendido aqui como parte da realidade social, pois o ser humano se distingue não só por agir, mas por pensar sobre o que faz e por interpretar suas ações dentro e a partir da realidade vivida e partilhada com seus semelhantes (MINAYO, 2009, p. 21).

No que se refere ao delineamento da pesquisa, de acordo com Gil (2008), a pesquisa pode ser classificada em: pesquisa bibliográfica, documental e estudo de campo. Gil (2008, p. 50) observa que a "pesquisa bibliográfica é desenvolvida a partir de materiais já elaborados, constituídos principalmente por livros e artigos científicos". Chagas (2012, p. 249) considera o levantamento bibliográfico como uma "consulta a diferentes documentos, para encontrar e selecionar material pertinente para a realização do trabalho". A partir disso, foi possível identificar documentos pertinentes para embasamento conceitual e teórico sobre o tema.

A seguir, são definidas as etapas de desenvolvimento da pesquisa que sistematizam o processo e mostram os procedimentos seguidos para alcançar os resultados. Para a coleta de dados, optou-se pelo questionário com perguntas fechadas e abertas e entrevista com roteiro pré-estabelecido.

O ambiente de pesquisa desta investigação é composto por escolas particulares de Florianópolis, que possuem ensino fundamental e médio, e contam com o mesmo bibliotecário no espaço da biblioteca, há pelo menos dois anos. Optou-se por investigar o ensino médio em razão de ser um grupo pouco estudado no Brasil; geralmente as pesquisas são voltadas para o ensino infantil e fundamental, o que atribui relevância a este estudo. Ademais, existe a preocupação de como esse grupo está sendo preparado para a pesquisa e para a aprendizagem autônoma, considerando que a universidade e a formação profissional estão muito próximas dessa realidade.

As escolas particulares foram escolhidas pelo fato de terem biblioteca em sua estrutura, sendo o principal critério para atender os objetivos desta pesquisa. Outro possível ambiente de pesquisa seriam as escolas públicas estaduais, porém a inexistência do cargo de bibliotecário nestes espaços, excluiu-as do corpus de pesquisa. Quanto à preferência por escolas que ofertam o ensino fundamental e médio, isto ocorreu por estas 


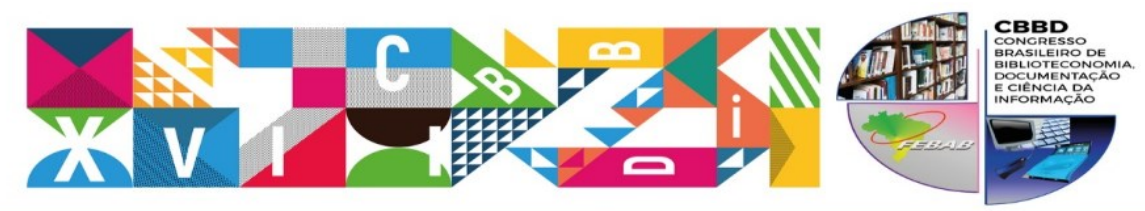

XXVII CONGRESSO BRASILEIRO DE BIBLIOTECONOMIA, DOCUMENTAÇÃO E CIÊNCIA DA INFORMAÇÃO

TEMA CENTRAL: Objetivos para o Desenvolvimento Sustentável das Naçōes Unidas:
como as bibliotecas podem contribuir com a implementaçăo da Agenda 2030

possibilitarem ao estudante um percurso gradativo na aprendizagem e na metodologia adotada, subsidiando o acúmulo de experiências e consequentemente agregando competências.

A atuação do bibliotecário na escola foi limitada há no mínimo dois anos, pois acredita-se ser um tempo hábil para o profissional se familiarizar com o ambiente escolar e suas características. A partir disso, o profissional passa a desenvolver suas ações baseadas nas características da escola juntamente com seu conhecimento profissional, possibilitando a concretização da sua atuação, gerando atividades e serviços na biblioteca, e parceria com os professores, por exemplo. Seguindo a metodologia descrita acima para obter os dados da pesquisa, na próxima seção, serão apresentadas a análise e a discussão dos resultados.

\section{RESULTADOS: APRESENTAÇÃO E DISCUSSÃO}

Esta seção se destina à análise e discussão dos resultados da pesquisa, as categorias adotadas têm como base os objetivos específicos da pesquisa. Acredita-se que o ambiente e sua estrutura juntamente com o perfil do bibliotecário contribuem para o desenvolvimento de atividades que constroem um perfil pesquisador nos estudantes. Fizeram parte da pesquisa oito bibliotecários de escolas da Rede Privada de Florianópolis.

\subsection{Caracterização das bibliotecas escolares}

No que se refere à caracterização das bibliotecas escolares, investigou-se o acervo, serviços oferecidos, recursos humanos, jornada de trabalho e atendimento, incentivo à formação continuada do bibliotecário e as principais mudanças ocorridas na biblioteca nos últimos anos. Esses dados foram obtidos por meio do questionário respondido pelos bibliotecários após a entrevista.

As bibliotecas investigadas fazem parte da estrutura de escolas privadas de Florianópolis/SC, estas possuem bibliotecário há mais de 10 anos e atendem ao ensino 


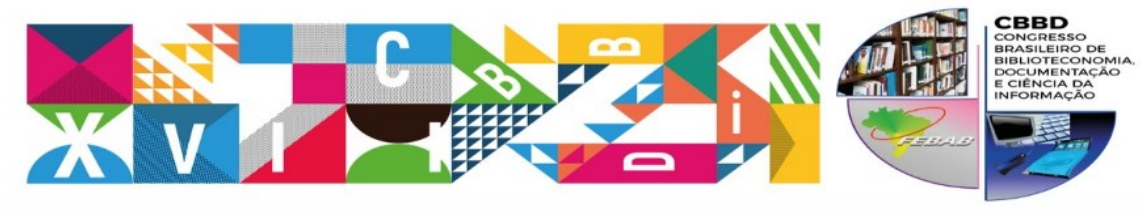

XXVII CONGRESSO BRASILEIRO DE BIBLIOTECONOMIA,

DOCUMENTAÇÃO E CIÊNCIA DA INFORMAÇĀO

TEMA CENrRal: Objetivos para o Desenvolvimento Sustentável das Naçōes Unidas:
como as bibliotecas podem contribuir com a implementaçăo da Agenda 2030

fundamental e médio. Verificou-se que o espaço da biblioteca é consolidado nessas escolas, pois disponibilizam uma boa infraestrutura, com profissionais qualificados em atuação. Durante as visitas, verificou-se que as bibliotecas possuem um espaço agradável e acolhedor, com estrutura física em boas condições para atender a comunidade escolar.

Para analisar a estrutura disponibilizada pelas bibliotecas baseou-se no Manifesto para Bibliotecas Escolares, assim analisaram-se o acervo, os produtos e serviços, e a equipe da biblioteca, que serão apresentados a seguir (FEDERAÇÃO INTERNACIONAL DE ASSOCIAÇÕES DE BIBLIOTECAS E INSTITUIÇÕES, 2002).

No que se referem ao acervo dessas bibliotecas, os dados sinalizam uma grande variação na quantidade de títulos ( 3 mil a 30 mil), porém, os tipos de obras que compõem o acervo se aproximam muito. 0 destaque fica com os livros de literatura, livros informativos para pesquisa, periódicos e obras de referência. A partir desses dados, percebe-se que as bibliotecas pesquisadas possuem em seus acervos, documentos adequados ao atendimento de um público escolar.

Além desses documentos, destaca-se que podem fazer parte do acervo os recursos informacionais de acesso eletrônico, por meio da Internet. Esse tipo de material não foi identificado nas respostas dos bibliotecários.

Seguindo a proposta pedagógica, é pertinente selecionar materiais diversificados, tendo em vista oportunizar aos estudantes esse contato no processo de aprendizagem, seja nos momentos de lazer ou pesquisa. A diversidade de informação permite ao estudante construir uma visão geral de como a informação está organizada e como buscála. Dessa forma, a biblioteca escolar na educação básica inicia a formação de crianças e adolescentes com um perfil apropriado para conviver na sociedade da informação.

Para contribuir na qualidade das informações disponíveis, a política de formação e desenvolvimento de coleções como uma ferramenta que auxilia a definir o propósito, a extensão e o conteúdo da coleção. Durante as visitas às escolas, solicitou-se o acesso a documentos e políticas, porém nenhuma biblioteca disponibilizava. Isso nos remete a falta de registros das atividades e normas da biblioteca. 0 registro facilita a preservação e a disseminação da informação daquela biblioteca. 


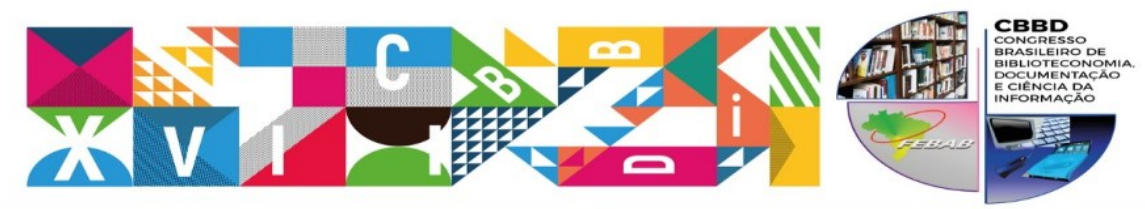

XXVII CONGRESSO BRASILEIRO DE BIBLIOTECONOMIA,

DOCUMENTAÇÃO E CIÊNCIA DA INFORMAÇÃO

TEMA CENIRAL: Objetivos para o Desenvolvimento Sustentável das Naçōes Unidas:
como as bibliotecas podem contribuir com a implementaçăo da Agenda 2030

Em relação aos serviços, a biblioteca escolar tem como missão promover serviços que apoiem à aprendizagem, o incentivo à leitura, possibilitando a formação de usuários da informação. Dessa forma, questionou-se quais serviços são oferecidos, destacaram-se os seguintes: empréstimo, orientação à pesquisa escolar, contação de história e serviço de referência (atendimento ao usuário). Alguns serviços chamaram a atenção por serem ações diversificadas e importantes para o ambiente escolar que vem ganhando espaço, como por exemplo, a parceria em projetos, ações culturais, educação de usuários e a divulgação do acervo pelo site e expositor.

Para atender de maneira satisfatória, tanto com a disponibilização de um bom acervo quanto com os serviços e produtos, é imprescindível que a biblioteca escolar conte com um bibliotecário para fazer o planejamento e gestão e com uma equipe adequada para apoiar as diferentes atividades ali desenvolvidas. Além disso, é importante trabalhar em conjunto com outros profissionais e manter contato com bibliotecários de outras instituições (FEDERAÇÃO INTERNACIONAL DE ASSOCIAÇÕES DE BIBLIOTECAS E INSTITUIÇÕES, 2000).

Em relação aos recursos humanos, constatou-se que três bibliotecas funcionam com apenas um bibliotecário para desempenhar todas as atividades; outras três escolas com um bibliotecário e um auxiliar e somente duas escolas possuem uma equipe com cinco pessoas no espaço da biblioteca. É relevante destacar que apenas três escolas ofertam vagas para estagiários do curso de biblioteconomia, e isso considerando que Florianópolis possui dois cursos de graduação. 0 contato entre o bibliotecário e o estagiário favorece tanto às escolas como aos estudantes, aproximando a teoria da prática e contribuindo para que futuros profissionais se identifiquem com o ambiente escolar.

Referente à carga horária de trabalhos semanal dos bibliotecários, os dados indicam que: quatro deles trabalham 40 horas, três mais de 40 horas e um trabalha 30 horas semanais. 0 horário de atendimento nas bibliotecas abrange todos os períodos da escola. Em alguns casos, a biblioteca permanece aberta por mais tempo com o atendimento dos auxiliares.

Verificou-se também a postura da escola no que se refere ao incentivo da formação continuada do bibliotecário. Seis dos bibliotecários afirmaram ter incentivos da escola Revista Brasileira de Biblioteconomia e Documentação - v. 13, n. esp. CBBD 2017 


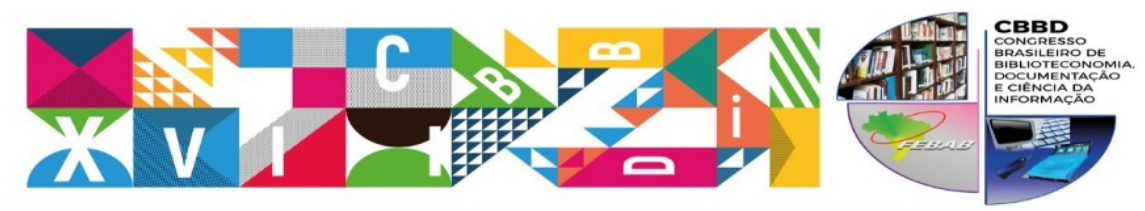

XXVII CONGRESSO BRASILEIRO DE BIBLIOTECONOMIA, DOCUMENTAÇÃO E CIÊNCIA DA INFORMAÇĀO

TEMA cENTrRL: Objetivos para o Desenvolvimento Sustentável das Naçōes Unidas:
como as bibliotecas podem contribuir com a implementaçăo da Agenda 2030

com liberação no horário de trabalho; apenas dois bibliotecários destacaram ter apoio financeiro, outros dois citaram o apoio e liberação em eventos promovidos pelo Sinepe, que é o sindicato das escolas privadas de Florianópolis.

A atuação em ambientes informacionais exige do profissional uma postura voltada para a aprendizagem constante. Valentim (2008) considera o contato com o ambiente científico e com os pares uma das principais formas para ampliar o conhecimento e trocar experiências. Isso contribui e reflete no desenvolvimento das atividades, no ambiente da biblioteca. Por isso, é fundamental que a escola reconheça essa prática e procure incentivar, afinal o grande beneficiado é o ambiente de trabalho.

A biblioteca escolar por muito tempo foi vista como um depósito. Aos poucos os bibliotecários vêm conquistando espaço dentro das escolas e promovendo diversas atividades. A partir disso, indagou-se quais foram as principais mudanças ocorridas desde o ingresso do bibliotecário na escola.

Ao questionar sobre as principais mudanças ocorridas na biblioteca desde o ingresso do bibliotecário na escola, o primeiro pensamento exposto era "nossa, foram muitas mudanças”. De maneira geral, destacaram-se as atividades voltadas para mudanças físicas e no relacionamento entre profissionais, novos serviços e a aproximação dos professores para desenvolver projetos.

Percebe-se que aos poucos as bibliotecas escolares estão saindo do paradigma físico, no qual a preocupação era voltada apenas para a organização do acervo. As atividades desenvolvidas que vêm ganhando espaço são voltadas para a aprendizagem por meio de projetos e parcerias com outros profissionais. Isso vem ao encontro do grande desafio da sociedade da informação que é preparar indivíduos para que se apropriem do rico ambiente informacional que vivemos.

\subsection{Perfil dos bibliotecários}

Nesta subseção, são apresentados os dados referentes ao perfil dos bibliotecários, buscou-se investigar a idade, formação acadêmica, a participação em eventos, tempo que 

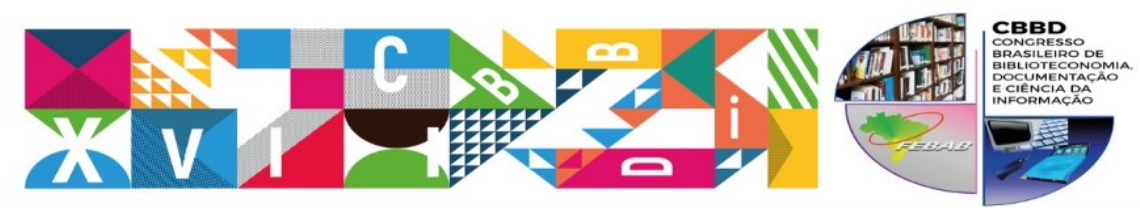

XXVII CONGRESSO BRASILEIRO DE BIBLIOTECONOMIA,

DOCUMENTAÇÃO E CIÊNCIA DA INFORMAÇĀO

TEMA CENrRal: Objetivos para o Desenvolvimento Sustentável das Naçōes Unidas:
como as bibliotecas podem contribuir com a implementaçăo da Agenda 2030

exerce a profissão, envolvimento com a classe e conhecimentos específicos sobre a área de atuação.

Acredita-se que o perfil profissional é um dos pilares que sustenta a prática profissional, juntamente com a infraestrutura e as práticas desenvolvidas, de acordo com o interesse do ambiente de trabalho, no caso, as escolas.

Quadro 1 - Dados dos bibliotecários

\begin{tabular}{|c|c|c|c|}
\hline Bibliotecários & Idade & $\begin{array}{l}\text { Tempo de exercício de } \\
\text { profissão }\end{array}$ & Instituição de Formação \\
\hline B1 & De 20 a 29 anos & De 3 a 5 anos & UDESC \\
\hline B2 & De 40 a 49 anos & De 3 a 5 anos & UFSC \\
\hline B3 & De 50 a 59 anos & Mais de 10 anos & UFSC \\
\hline B4 & De 30 a 39 anos & De 3 a 5 anos & UFSC \\
\hline B5 & De 30 a 39 anos & De 3 a 5 anos & UFSC \\
\hline B6 & De 50 a 59 anos & Mais de 10 anos & UDESC \\
\hline B7 & De 20 a 29 anos & De 6 a 10 anos & FESP \\
\hline B8 & De 20 a 29 anos & De 6 a 10 anos & UDESC \\
\hline
\end{tabular}

Fonte: Dados obtidos na pesquisa, 2017.

A partir dos dados coletados, no quadro 1 é possível visualizar de maneira geral o perfil de cada entrevistado e o cuidado que se teve com a preservação da identidade. No que se refere a faixa etária a maioria possui entre 20 a 39 anos, 50\% concluiu a graduação em Biblioteconomia na Universidade Federal de Santa Catarina (UFSC). Quanto à formação continuada, o destaque ficou concentrado nos cursos de especialização nas seguintes áreas: gestão de bibliotecas escolares, gestão de pessoas, gestão de projetos e educação especial. Percebe-se que os bibliotecários buscaram temas diretamente relacionados com a atuação escolar.

Tem em vista as exigências da sociedade atual, a formação continuada é considerada indispensável, principalmente para o bibliotecário que tem a informação como elemento central em suas atividades. De acordo com Valentim (2008), é preciso avaliar e repensar as formas de trabalho, pois as mudanças sociais e tecnológicas afetamnas diretamente. Sendo assim, é pertinente que o bibliotecário tenha uma postura criativa para desenvolver ações que contribuam com a aprendizagem dos estudantes de educação básica, principalmente do ensino médio, foco desta pesquisa. 


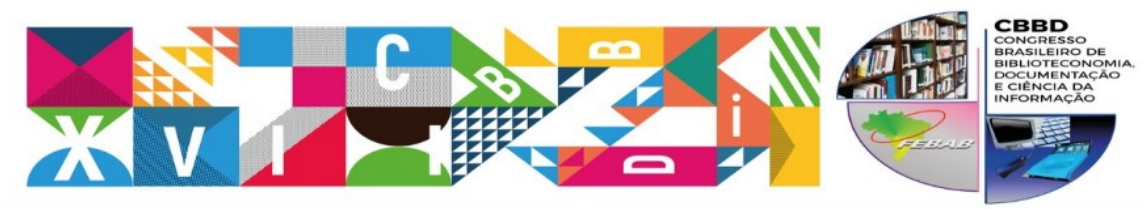

XXVII CONGRESSO BRASILEIRO DE BIBLIOTECONOMIA, DOCUMENTAÇÃO E CIÊNCIA DA INFORMAÇÃO

TEMA CENTRAL: Objetivos para o Desenvolvimento Sustentável das Naçōes Unidas:
como as bibliotecas podem contribuir com a implementaçăo da Agenda 2030

Buscar formações que auxiliem o profissional a se inserir no ambiente de trabalho é uma boa estratégia. Tendo em vista, a necessidade de estar em sintonia com a realidade onde atua, no caso da biblioteca escolar, a procura por assuntos pedagógicos, de leitura e pesquisa são essenciais.

No que se refere ao contato com profissionais de outras instituições, Valentim (2008) considera que essa interação permite a socialização de conhecimento e experiências que viabilizam a ampliação da visão de trabalho, novos serviços e produtos.

Ao questionar sobre o contato com bibliotecários de outras instituições, sete dos entrevistados afirmaram não ter contato, apenas uma resposta foi positiva. Percebe-se que o bibliotecário escolar carece de iniciativas voltadas para contato profissional, que permite uma troca de informações e experiências. Além disso, contribui para o crescimento pessoal e profissional, pois é convivendo com outras pessoas que se discute, aprende, socializa e consequentemente melhoram-se as práticas e os posicionamentos. A falta desse contato pode acarretar isolamento e desatualização do profissional.

Ao perguntar sobre a Associação Catarinense de Bibliotecários (ACB), sete bibliotecários afirmaram que conhecem, porém não são sócios e pouco participam das atividades promovidas; apenas um desconhece. 0 fato que chamou mais a atenção foi o de que nenhum bibliotecário respondeu que participa ativamente dos eventos e discussões, considerando que a ACB (2017) tem como missão "congregar a classe bibliotecária, aprimorar competências e fortalecer a categoria no Estado”.

Além do mais, pelo fato da ACB ter sua sede na grande Florianópolis, pode-se considerar um privilégio, devido à concentração de eventos nessa região, o que não é realidade nas demais regiões do estado de Santa Catarina.

A participação em eventos da área é outra oportunidade de manter-se atualizado e fazer contatos profissionais. Ao questionar sobre a participação dos bibliotecários em eventos da área, destacaram-se os eventos voltados para a contação de histórias, incentivo à leitura, eventos da área de pedagogia e biblioteconomia. Vale destacar que os eventos renomados do estado e promovidos pelas Instituições de Ensino Superior e pela Associação não foram citados pelos profissionais. Apenas um bibliotecário diz ter 


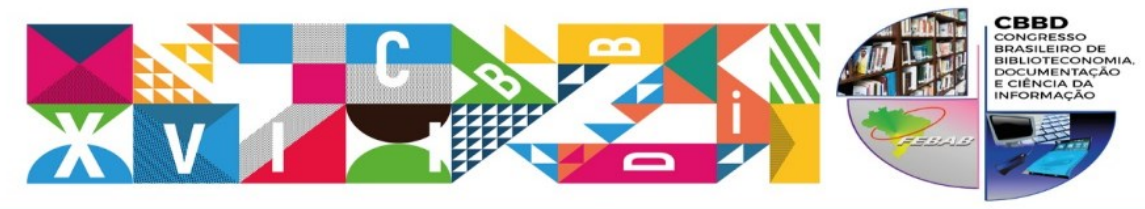

XXVII CONGRESSO BRASILEIRO DE BIBLIOTECONOMIA,

DOCUMENTAÇÃO E CIÊNCIA DA INFORMAÇÃO

TEMA CENTRAL: Objetivos para o Desenvolvimento Sustentável das Naçōes Unidas:
como as bibliotecas podem contribuir com a implementaçăo da Agenda 2030

participado do Painel de Biblioteconomia, principal evento da classe biblioteconômica, no estado.

Ainda sobre o perfil do bibliotecário, investigou-se o conhecimento a respeito das fontes de pesquisa. Nesta pesquisa, considera-se parte do perfil o interesse por buscar, selecionar, utilizar e recomendar fontes de pesquisa no ambiente escolar. Silva e Cunha (2016) alegam que o bibliotecário possui competências para estimular e desenvolver habilidades nos estudantes para buscar, recuperar, avaliar e usar a informação em diversos suportes.

Levando em consideração que a pesquisa escolar é uma das principais atividades desenvolvidas pelo bibliotecário, segundo Rodrigues (2004) a oferta de um local apropriado para o seu desenvolvimento inclui disponibilizar fontes de pesquisa adequadas de acordo com a idade e disciplina. Assim, a biblioteca é vista por Silva e Cunha (2016, p. 47) como um local que agrupa diferentes fontes de informação, sendo assim, compete ao "bibliotecário utilizar desses materiais para empreender serviços informacionais a comunidade escolar".

No que se refere ao conhecimento dos bibliotecários em relação às fontes de pesquisa impressas, três bibliotecários apontaram que "conhece, utiliza e recomenda", dois que "conhece e utiliza", dois que "conhece, mas não utiliza", e um afirmou que desconhece. As fontes que se destacaram nas respostas dos bibliotecários são as enciclopédias, livros de pesquisa e revistas.

No que se refere às fontes de pesquisa virtual, quatro dos bibliotecários assinalaram que "conhece, mas não utiliza", dois "conhece, utiliza e recomenda para os alunos" e outros dois "desconhece". Percebeu-se a dificuldade em citar quais fontes são utilizadas no meio virtual durante a pesquisa escolar. Mais da metade dos bibliotecários deixaram a questão em branco.

Após caracterizar as bibliotecas escolares e identificar o perfil dos bibliotecários atuantes, na subseção a seguir, serão apresentadas possíveis ações que podem contribuir na formação de estudantes pesquisadores na educação básica. 


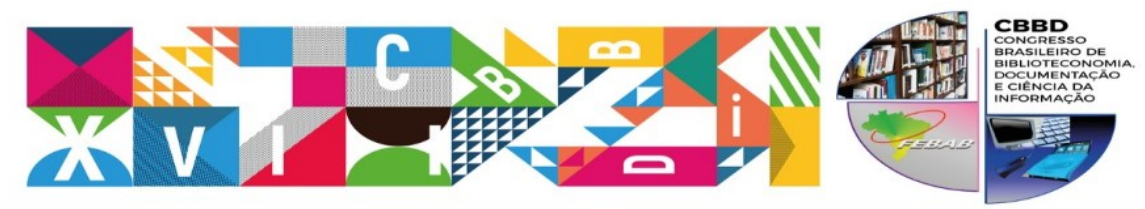

XXVII CONGRESSO BRASILEIRO DE BIBLIOTECONOMIA, DOCUMENTAÇÃO E CIÊNCIA DA INFORMAÇĀO

TEMA cENTrRL: Objetivos para o Desenvolvimento Sustentável das Naçōes Unidas:
como as bibliotecas podem contribuir com a implementaçăo da Agenda 2030

\subsection{Ações desenvolvidas na formação de pesquisadores}

Nesta subseção, serão analisadas as ações desenvolvidas pelos bibliotecários pesquisados que podem contribuir para o desenvolvimento das habilidades em pesquisa nos estudantes. Buscou-se investigar as relações do bibliotecário com outros setores da escola, sua atuação no que se refere à pesquisa escolar, ao uso da biblioteca e das fontes de informação. Para iniciar, acredita-se que a integração da biblioteca com a sala de aula e outros ambientes da escola, contribui no planejamento e desenvolvimento das atividades.

Dessa forma, verificaram-se três perfis de participação nas reuniões pedagógicas: a) o profissional que participam das reuniões pedagógicas, porém durante a fala não apresentam qual sua contribuição no processo, esse foi o perfil que mais prevaleceu no corpus da pesquisa; b) o profissional que não participam das reuniões pedagógicas, é o segundo perfil que mais aparece, destaca-se que é perceptível o desgosto com este fato, porém, ainda não conseguiram conquistar esse espaço dentro da escola; e c) o profissional que tem clareza de sua participação, sabe como cooperar, tem acesso às avalições e contribui com o planejamento, possibilitando envolver a biblioteca tanto com o planejamento do professor quanto com as atividades que abrangem a escola, esse perfil teve uma baixa representatividade.

Nesta pesquisa, considerou-se importante a participação do bibliotecário nas reuniões pedagógicas, pois é um espaço de integração e planejamento. A partir do momento em que o bibliotecário participa e contribui fica visível sua inserção no ambiente escolar e nas relações de trabalho, que só tem a agregar no desenvolvimento da educação.

A partir disso, investigou-se a existência do trabalho de cooperação entre bibliotecário e professor. Essa parceria promove o desenvolvimento de uma aprendizagem mais dinâmica e criativa, potencializando o trabalho do professor e do bibliotecário, e favorecendo aos estudantes o contato com a informação e o conhecimento de maneira participativa (RODRIGUES, 2004; SILVA; CUNHA, 2016). 


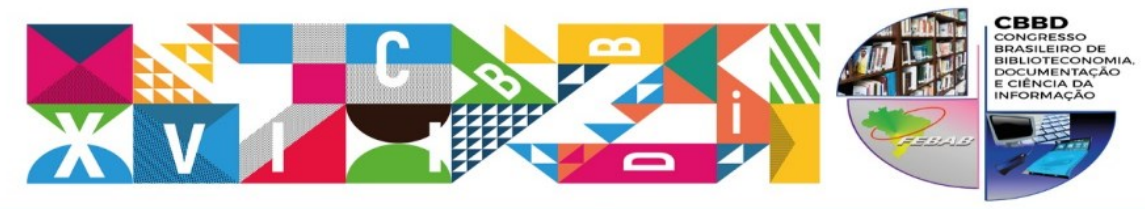

XXVII CONGRESSO BRASILEIRO DE BIBLIOTECONOMIA,

DOCUMENTAÇÃO E CIÊNCIA DA INFORMAÇÃO

TEMA CENIRAL: Objetivos para o Desenvolvimento Sustentável das Naçōes Unidas:
como as bibliotecas podem contribuir com a implementaçăo da Agenda 2030

Constatou-se que a parceria é um fator importante para o desenvolvimento dos trabalhos na biblioteca. 0 que chama a atenção é a iniciativa por parte do bibliotecário em buscar parcerias, em estar disposto a novos desafios e projetos em conjunto com os professores. Algumas atividades como a escolha do acervo, o acompanhamento do planejamento de sala de aula e o desenvolvimento de projetos são mencionados pelos profissionais.

No contexto escolar, o bibliotecário é visto com a função de professor segundo Campello (2003), devido a sua responsabilidade de ensinar não apenas habilidades informacionais, mas também de pensar criticamente esse processo. Além do mais, o trabalho em conjunto com os professores beneficia o desenvolvimento intelectual de acordo com Rodrigues (2004), pois o contato com a informação e o conhecimento favorece na ampliação do senso crítico e na criatividade.

Investigou-se também a existência do planejamento em conjunto com o professor no que se refere à pesquisa escolar e ao uso da biblioteca. 0 contato com as fontes de informação e com as habilidades de pesquisa permitem aos estudantes explorar os conteúdos trabalhados em sala de aula. Por isso, é preciso planejar e alinhar os conteúdos trabalhados pelos professores em sala de aula com as possibilidades da biblioteca.

Ao questionar sobre a existência do planejamento de forma geral encontrou-se uma realidade de colaboração, na qual o bibliotecário disponibiliza uma lista de opções com o acervo da biblioteca que podem contribuir com os conteúdos disponíveis em sala de aula. Ainda, deparou-se com realidades que realizam planejamentos de uso da biblioteca voltado apenas para a troca de livros, assim, a maioria dos horários fica ocupada com as visitas das turmas para realizar empréstimo e devolução. A atividade de pesquisa pode ser agendada mediante conversa prévia, porém os horários são bem limitados. As atividades que envolvem planejamento e projetos para as turmas conhecerem a biblioteca, seus serviços e sua importância, são ações isoladas, que ainda precisam crescer e atingir um público maior.

Nesta pesquisa, os dados revelam que o planejamento existente nas bibliotecas é mais voltado para o empréstimo de livros. Esperava-se encontrar um planejamento mais especifico para o uso da biblioteca, no que se refere à formação de usuários, em como usáRevista Brasileira de Biblioteconomia e Documentação - v. 13, n. esp. CBBD 2017 


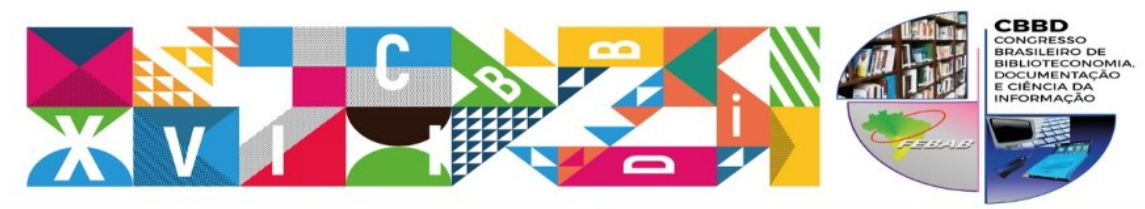

XXVII CONGRESSO BRASILEIRO DE BIBLIOTECONOMIA, DOCUMENTAÇÃO E CIÊNCIA DA INFORMAÇĀO

TEMA cENTrRL: Objetivos para o Desenvolvimento Sustentável das Naçōes Unidas:
como as bibliotecas podem contribuir com a implementaçăo da Agenda 2030

la, seus serviços e sua importância, além da contribuição do bibliotecário em cada etapa da pesquisa escolar. Isso porque quando existe um trabalho de cooperação, é importante haver planejamento para definir as funções de cada envolvido, definir as etapas e datas para que ocorra com sucesso.

0 trabalho em conjunto traz muitos benefícios para o ambiente escolar e principalmente na aprendizagem dos estudantes. A partir do momento que existe uma parceria no trabalho, questionou-se sobre a participação do bibliotecário no processo de pesquisa escolar, levando em consideração que este processo geralmente está atrelado a uma disciplina. Essa participação é muito rica, devido aos conhecimentos relacionados ás fontes de informação e o processo de pesquisa em si (buscar, recuperar, avaliar e usar) que podem contribuem com as atividades desenvolvidas pelo professor nos mais diversos assuntos e disciplinas (RODRIGUES, 2004; SILVA; CUNHA, 2016).

Ao questionar os bibliotecários sobre sua participação no processo de pesquisa escolar encontrou-se dois grupos distintos: os profissionais que desenvolvem atividades isoladas, pois ainda não desenvolveu uma cultura de aprendizagem por meio da pesquisa, e a escola ainda não se tem clareza dos benefícios que essa interação pode trazer a longo prazo. E grupo dos profissionais que já conquistaram esse espaço atua juntamente com o professor no processo de pesquisa, tem clareza da importância e de sua contribuição nesse processo.

Destacou-se o trabalho realizado por uma bibliotecária, devido aos seus cuidados com as questões de normalização de trabalhos e com a pesquisa escolar. Durante a entrevista, foi possível ter acesso aos manuais, sendo que os mesmos estão separados em dois módulos: ensino fundamental e ensino médio, no modelo folheto.

Nessa biblioteca, a pesquisa escolar no módulo ensino fundamental é trabalhada de uma forma lúdica e simples, iniciando a conscientização do uso e da busca da informação para os trabalhos escolares. No módulo ensino médio já inicia uma preparação para a universidade e para a pesquisa cientifica, criando um primeiro contato com a ciência e com a forma que o conhecimento é organizado e utilizado.

Os manuais são entregues aos estudantes e professores. No material, é destacada a importância da leitura, as etapas da pesquisa escolar (identificação, busca e coleta de Revista Brasileira de Biblioteconomia e Documentação - v. 13, n. esp. CBBD 2017 


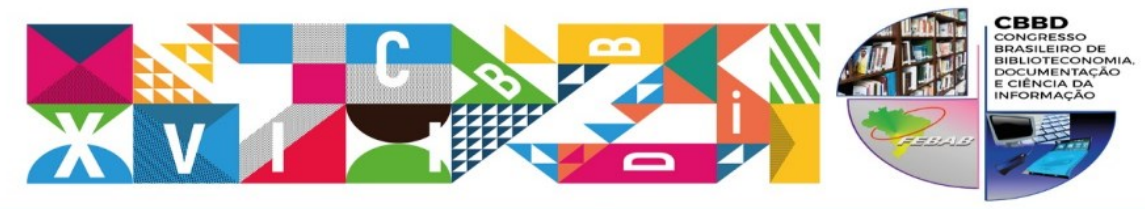

XXVII CONGRESSO BRASILEIRO DE BIBLIOTECONOMIA, DOCUMENTAÇÃO E CIÊNCIA DA INFORMAÇĀO

TEMA cENTrRL: Objetivos para o Desenvolvimento Sustentável das Naçōes Unidas:
como as bibliotecas podem contribuir com a implementaçăo da Agenda 2030

informações, análise, seleção, comunicação e avaliação) e as fontes confiáveis que são encontradas na biblioteca e na Internet. Percebe-se que os manuais seguem uma metodologia adequada e de acordo com a literatura. Segundo Kuhlthau (2010), a pesquisa escolar é uma prática de aprendizagem fundamentada em processos que deve envolver a localização, seleção e uso da informação.

Juntamente com a pesquisa escolar, outras atividades podem ser desenvolvidas. Uma das atividades que é de responsabilidade do bibliotecário na formação dos estudantes, diz respeito ao uso da biblioteca e das fontes de informação. Essas atividades visam desenvolver habilidades desde a educação básica, para usar os recursos informacionais, isso envolve habilidade de localizar, selecionar e usar informações, de forma sequencial e sistematizada (KUHLTHAU, 2009).

Atividades simples podem auxiliar os estudantes na formação de uma visão geral de como a informação está organizada, instigando a curiosidade e preparando-os para buscar e utilizar a informação. É possível perceber um esforço por porte do bibliotecário para inserir as fontes de informação nas ações diárias, no início do ano letivo a biblioteca é apresentada para os estudantes, oportunizando assim, uma maior familiaridade com o ambiente, com a forma de organização do espaço, como utilizar a biblioteca e como localizar o acervo. Esse tipo de atividade instigado desde a educação básica permite aos estudantes criar uma rotina com os espaços de informação.

A existência de ações voltadas para a aprendizagem do uso da biblioteca e das fontes de informação. 0 desenvolvimento dos manuais de pesquisa e de formatação de trabalho têm auxiliado tanto os estudantes como os professores durante as atividades. A orientação da pesquisa ainda é feita de forma isolada, quando o estudante busca o auxílio do profissional. É interessante ressaltar a fala da bibliotecária ao abordar que a inserção de projetos na biblioteca escolar é uma grande luta, que pode ser melhorada a cada dia.

Em relação ao uso das fontes de informação, fica evidente a inexistência de projetos estruturados e consolidados por parte do bibliotecário. É perceptível a falta de conhecimento específico sobre a pesquisa escolar que acaba se confundindo com a formatação de trabalhos por parte do profissional. 


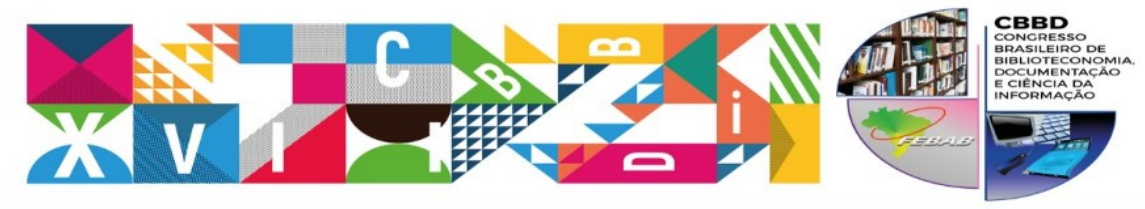

XXVII CONGRESSO BRASILEIRO DE BIBLIOTECONOMIA, DOCUMENTAÇÃO E CIÊNCIA DA INFORMAÇĀO

TEMA cENTrRL: Objetivos para o Desenvolvimento Sustentável das Naçōes Unidas:
como as bibliotecas podem contribuir com a implementaçăo da Agenda 2030

O envolvimento com a pesquisa e com as fontes acontece quando o estudante solicita ajuda, a falta de iniciativa para apresentar suas habilidades e contribuir de forma efetiva ainda é uma realidade quando se trata de atuação na pesquisa escolar. Geralmente os estudantes fazem as pesquisas sozinhos nos computadores e imprimem, sem interferência do bibliotecário.

Ainda existem visões limitas quanto ao uso da biblioteca, os estudantes utilizam mais para empréstimo de livros, do que para a pesquisa. Logo, as atividades voltadas para o uso da biblioteca e das fontes de informação são precárias. Porém, o bibliotecário em seu discurso reconhece a necessidade e importância de tais atividades.

Em relação à formação dos usuários para pesquisas no ambiente virtual, Furtado (2013) observa que o bibliotecário possui habilidades que contribuem na educação de usuários, isso envolve o uso dos recursos da web, a pesquisar em sites específicos e seguros, o uso de documentos textuais e digitais, e sempre respeitando os diretos autorais.

Abordou-se também na entrevista se o bibliotecário utiliza algum método específico de pesquisa na orientação aos estudantes. Campello (2012) ressalta que ao incorporar na prática de pesquisa, métodos de ensino fundamentados em fatos e comprovações científicas, existe uma probabilidade maior na eficiência das ações. Tendo em vista que esses métodos já foram estudados e testados nas universidades, o bibliotecário pode incorporar em sua prática, garantindo maior qualidade nas atividades por ter embasamento teórico.

Em geral, percebeu-se um desconhecimento do bibliotecário quanto ao uso de métodos de pesquisa. Em algumas entrevistas nota-se certa confusão com as normas da ANBT e normalização de trabalhos ao falar sobre pesquisa escolar. A maioria deixa claro que não é realizada pesquisa escolar na biblioteca, por isso não existe uma preocupação em utilizar algum método, apenas se algum estudante procura é feita uma orientação de forma individual.

Apenas um bibliotecário, descreveu todas as etapas da pesquisa, ainda destaca o material elaborado por ele para orientar os estudantes e professores na pesquisa. Podese perceber que o processo é bem definido, com embasamento teórico e adaptado numa linguagem simples para o público alvo.

Revista Brasileira de Biblioteconomia e Documentação - v. 13, n. esp. CBBD 2017 


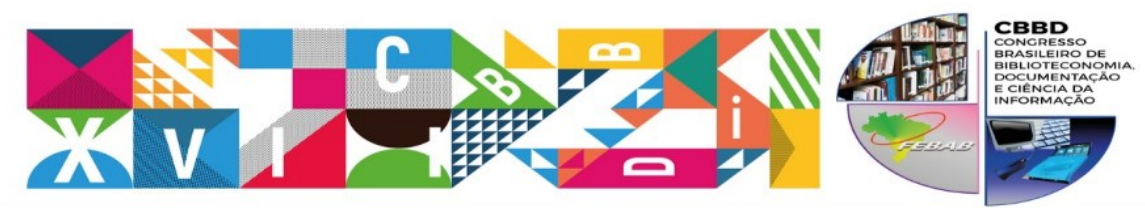

XXVII CONGRESSO BRASILEIRO DE BIBLIOTECONOMIA, DOCUMENTAÇÃO E CIÊNCIA DA INFORMAÇĀO

TEMA CENrRal: Objetivos para o Desenvolvimento Sustentável das Naçōes Unidas:
como as bibliotecas podem contribuir com a implementaçăo da Agenda 2030

Para finalizar, investigaram-se quais atividades o bibliotecário considera que contribuem na formação de estudantes pesquisadores. Isso porque acredita-se que por trás de cada atividade desenvolvida existe um benefício bem maior; que quando a pesquisa é embasada em teorias e conceitos ganha mais significado e visibilidade.

Destacou-se o desenvolvimento de manuais de pesquisa como um dos principais na formação de pesquisadores, pois desde as séries iniciais é trabalhada a pesquisa escolar de uma forma lúdica. Ao chegar ao ensino médio, o estudante já tem uma base, pode-se considerar que existe uma evolução no entendimento e na aplicação desses conceitos e métodos. Para mais, ressaltou-se que qualquer atividade que incentive a leitura vai contribuir na formação de um bom pesquisador, pois a leitura é uma atividade básica na construção do conhecimento.

\section{CONSIDERAÇÕES FINAIS}

No cenário atual, a informação é matéria prima para qualquer atividade humana. Diante disso, torna-se essencial preparar as pessoas desde a educação básica para o uso da informação. Assim, a pesquisa escolar é uma das possibilidades de aprendizagem, por meio da resolução de problemas que envolve a busca, seleção, leitura, utilização e o compartilhamento de informações.

Diante da proposta de pesquisa, conclui-se que os bibliotecários escolares podem colaborar na formação de estudantes pesquisadores, por meio da disponibilização de um espaço propício para o desenvolvimento da pesquisa escolar, com um acervo diversificado, serviços e produtos alinhados com as necessidades da comunidade escolar. Além disso, um ambiente que instigue a curiosidade, a criatividade e a interação são promissores para o incentivo e desenvolvimento dos estudantes.

Somando a isso, a partir do perfil pesquisador do bibliotecário, que se expressa em suas atitudes, que pesquisa, sintetiza, registra e dissemina informações no ambiente escolar, consequentemente vai impactar e instigar o desenvolvimento pesquisador dos estudantes. Por exemplo, se o bibliotecário sente a necessidade de conhecer as fontes de 


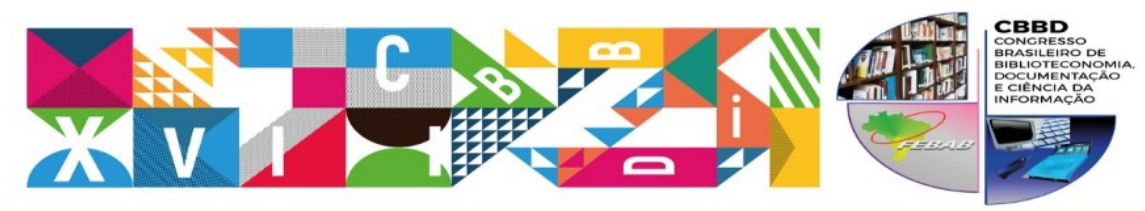

XXVII CONGRESSO BRASILEIRO DE BIBLIOTECONOMIA, DOCUMENTAÇÃO E CIÊNCIA DA INFORMAÇĀO

TEMA CENrRal: Objetivos para o Desenvolvimento Sustentável das Naçōes Unidas:
como as bibliotecas podem contribuir com a implementaçăo da Agenda 2030

informação úteis para o ambiente escolar, ele realiza uma busca, seleciona, sintetiza, registra e dissemina, além de estar colocando em prática suas habilidades e competências e pode realizar ações para potencializar o desenvolvimento dos estudantes, proporcionando o contato a busca de informação, a leitura e apropriação do conteúdo.

Esses conhecimentos específicos do bibliotecário no que tange as fontes de informação digitais e impressas, as etapas da pesquisa, suas competências em informação, quando compartilhada no ambiente escolar auxilia no desenvolvimento do perfil pesquisador no estudante.

Assim, percebe-se a forte ligação entre o perfil do bibliotecário e as ações que desenvolve no ambiente escolar, como é influenciador. Destaca-se as ações que envolvem o uso da informação durante a aprendizagem, o fortalecimento de parceria e o desenvolvimento de projetos com os professores, o incentivo a leitura, atividades que viabilizem conhecer o ambiente informacional e proporcionem o desenvolvimento de habilidades e competências para buscar e usar a informação.

Posto isto, acredita-se que esta pesquisa possa incentivar o reconhecimento do bibliotecário, e consequentemente da biblioteca no ambiente escolar, despertando o interesse por sua existência, mas com qualidade, em escolas que ainda não a possuem.

\section{REFERÊNCIAS}

ASSOCIAÇÃO CATARINENSE DE BIBLIOTECÁRIOS. Painel Biblioteconomia em Santa

Catarina, 2016. Disponível em: <http://acb.emnuvens.com.br/painel-biblioteconomia-de-santacatarina/>. Acesso em: 16 mar. 2017.

BAGNO, M. Pesquisa na escola: o que é, como se faz. 5.ed. São Paulo: Loyola, 2000.

BARRETO, A. A. A questão da informação. Revista São Paulo em Perspectiva. São Paulo, v. 8, n. 4, 1994. Disponível em:

<http://bogliolo.eci.ufmg.br/downloads/BARRET0\%20A\%20Questao\%20da\%20Informacao.p df >. Acesso em: 1 jul. 2017.

CAMPELLO, B. O movimento da competência informacional: uma perspectiva para o letramento informacional. Ciência da Informação, Brasília, v. 32, n. 3, p.28-37, 2003. Disponível em: <http://www.scielo.br/pdf/ci/v32n3/19021.pdf>. Acesso em: 3 set. 2017. 


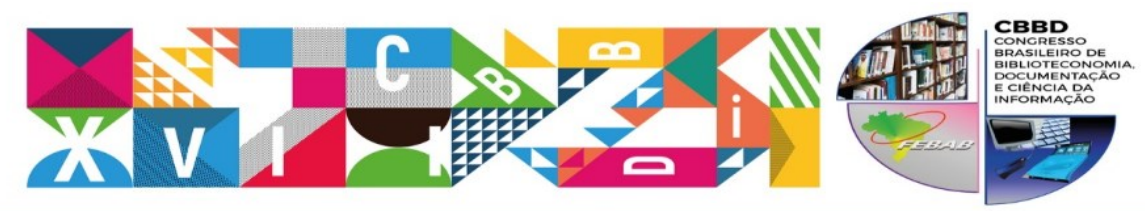

XXVII CONGRESSO BRASILEIRO DE BIBLIOTECONOMIA, DOCUMENTAÇÃO E CIÊNCIA DA INFORMAÇĀO

TEMA cENTrRL: Objetivos para o Desenvolvimento Sustentável das Naçōes Unidas:
como as bibliotecas podem contribuir com a implementaçăo da Agenda 2030

CAMPELLO, B. S. Biblioteca e Parâmetros Curriculares Nacionais. IN: CAMPELLO, B. S. et al ... A Biblioteca escolar: temas para uma prática pedagógica. 2.ed. Belo Horizonte: Autêntica, 2008. p. 17-20.

CAMPELLO, B. S. Biblioteca escolar: conhecimentos que sustentam a prática. Belo Horizonte: Autêntica, 2012.

CHAGAS, M. T. Disseminação da informação em bibliotecas escolares. Florianópolis: CIN/CED/UFSC, 2010.

CHAGAS, M. T. Novos rumos da biblioteca escolar. Florianópolis: CIN/CED/UFSC, 2009.

CHAGAS, Magda. Como fazer pesquisa bibliográfica e a formatação de referências e ilustrações. In: Duílio de Avila Bêrni; Brena Paula Magno Fernandez. (Org.). Métodos e Técnicas de Pesquisa: modelando as ciências empresariais. 1ed.São Paulo: Saraiva, 2012, v. 1, p. 247-278.

DURBAN ROCA, G. Biblioteca escolar hoje: recurso estratégico para a escola. Porto Alegre: Penso, 2012.

FEDERAÇÃO INTERNACIONAL DE ASSOCIAÇÕES DE BIBLIOTECAS E INSTITUIÇÕES. Diretrizes da IFLA/UNESCO para a biblioteca escolar. 2002. Disponível em:

<http://www.ifla.org/files/assets/school-libraries-resource-centers/publications/schoollibrary-guidelines/school-library-guidelines-pt_br.pdf>. Acesso em: 25 fev. 2017.

FEDERAÇÃO INTERNACIONAL DE ASSOCIAÇÕES DE BIBLIOTECAS E INSTITUIÇÕES. Manifesto para as Bibliotecas Escolares. 2000. Disponível em: <http://www.ifla.org/files/assets/schoollibraries-resource-centers/publications/school-library-guidelines/school-library-guidelinespt.pdf>. Acesso em: 15 fev. 2017.

FURTADO, C. Biblioteca escolar Brasileira no Contexto da Sociedade da Informação. In: Encontro Nacional de Pesquisa em Ciência da Informação, IV, Brasília, 06 a 10 de novembro de 2000.

Anais ... Disponível em:

<http://enancib.ibict.br/index.php/enancib/ivenancib/paper/view/2385>. Acesso em: 5 maio 2017.

FUSATTO, M. P.; SILVA, M.R. As bibliotecas e os bibliotecários: afinando competências. Biblioteca escolar em Revista, Ribeirão Preto, v. 3, n. 1, p.51-72, 2014.

Disponível em: <http://revistas.ffclrp.usp.br/BEREV/article/viewFile/340/pdf>. Acesso em: 25 mar. 2017.

GIL, A. C. Como elaborar projetos de pesquisa. São Paulo: Atlas, 2010.

GIL, A. C. Métodos e técnicas de pesquisa social. 6. ed. São Paulo: Atlas, 2008.

KUHLTHAU, C. Como orientar a pesquisa escolar: estratégias para o processo de aprendizagem. Belo Horizonte: Autêntica, 2010. 


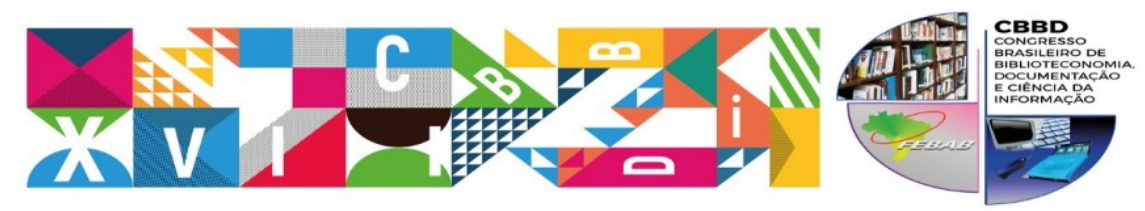

XXVII CONGRESSO BRASILEIRO DE BIBLIOTECONOMIA, DOCUMENTAÇÃO E CIÊNCIA DA INFORMAÇĀO

TEMA CENTrRa: Objetivos para o Desenvolvimento Sustentável das Naçōes Unidas:
como as bibliotecas podem contribuir com a implementaçăo da Agenda 2030

KUHLTHAU, C. Como usar a biblioteca na escola: um programa de atividades para o ensino fundamental. Belo Horizonte: Autêntica, 2009.

MILANESI, L. O que e biblioteca. São Paulo: Brasiliense, 1983.

MINAYO, M. C. S. O desafio da pesquisa social. In: MINAYO, Maria Cecilia de Souza; DESLANDES, Suely Ferreira; GOMES, Romeu. Pesquisa social: teoria, método e criatividade. 28. ed. Petrópolis: Vozes, 2008. p. 9-30.

MORO, E. L. S.; ESTABEL, L. B. A pesquisa escolar propiciando a integração dos atores - alunos, educadores e bibliotecários - irradiando o benefício coletivo e a cidadania em um ambiente de aprendizagem mediado por computador. Revista Renote: Novas Tecnologias na

Educação, Porto Alegre, v. 2, n. 1, p.1-10, mar. 2004. Disponível em:

<http://seer.ufrgs.br/index.php/renote/article/view/13662>. Acesso em: 5 abr. 2017.

PIERUCCINI, I. A busca do conhecimento na escola: a pesquisa escolar e a construção do conhecimento. Salto para o Futuro. Rio de Janeiro, v. 15, 2007. p. 49-64.

PIMENTEL, G.; BERNARDES, L; SANTANA, M. Biblioteca escolar. Brasília: Universidade de Brasília, 2007.

RASCHE, F. Pesquisa Escolar. Florianópolis: CIN/CED/UFSC, 2010.

RODRIGUES, Â. B. L. A biblioteca escolar como diferencial na compra dos serviços educacionais. In: Seminário Biblioteca escolar: espaço de ação pedagógica, 3., 2004, Belo Horizonte. Anais... Belo Horizonte: GEBE, 2005. p. 31-49. Disponível em:

<http://gebe.eci.ufmg.br/downloads/322.pdf>. Acesso em: 1 maio 2017.

SARACEVIC, T. Ciência da Informação: origem, evolução e relações. Perspectivas em Ciência da Informação, Belo Horizonte, v. 1, n.1, p. 41-62, 1996.

SILVA, E. L.; MENEZES, E. M. Metodologia da pesquisa e elaboração de dissertação. 4. ed. rev. atual. Florianópolis: UFSC, 2005.

SILVA, J.D. O. da; CUNHA, J. de A. O papel educativo da biblioteca escolar no contexto do Plano Nacional de Educação. Encontros Bibli, Florianópolis, v. 21, n. 46, p. 45-58, abr. 2016.

Disponível em: <https://periodicos.ufsc.br/index.php/eb/article/view/38695>. Acesso em: 17 maio 2017.

TAKAHASHI, T. Sociedade da informação no Brasil: livro verde. Brasília, Distrito Federal: Ministério da Ciência e Tecnologia, 2000.

VALENTIM, M.L.P. Criatividade e inovação na atuação profissional. CRB-8 Digital, v.1, n.1, p. 3-9, jul. 2008. Disponível em: <http://revista.crb8.org.br/index.php/crb8digital/article/view/36>. Acesso em: 8 abr. 2017.

VIDOTTI, S. A. B. G.; LANZI, L. A. C.; FERNEDA, E. A mediação da informação aliada ao uso das tecnologias da informação e comunicação em uma biblioteca escolar. Informação e 


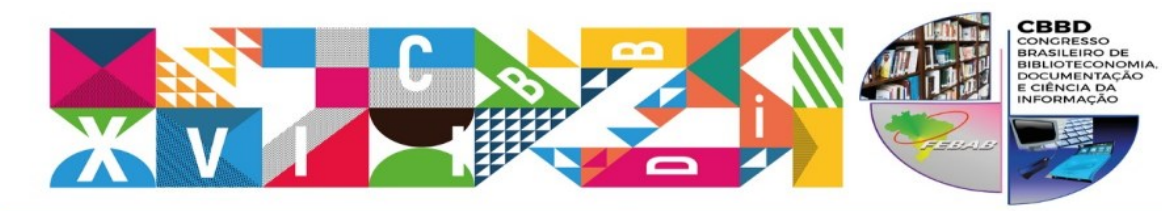

XXVII CONGRESSO BRASILEIRO DE BIBLIOTECONOMIA,
DOCUMENTAÇÃO E CIÊNCIA DA INFORMAÇĀO
TEMA central: Objetivos para o Desenvolvimento Sustentável das Naçōes Unidas:
como as bibliotecas podem contribuir com a implementação da Agenda 2030

Informação, Londrina, v. 19, n. 2, p.117-137, maio./ago. 2014. Disponível em:

<http://www.uel.br/revistas/uel/index.php/informacao/article/view/19997/pdf_22>. Acesso em: 18 abr. 2017. 